\title{
Mediating the effect of organizational culture on the relationship between training and develop-
} ment and organizational performance

\author{
Mohd Izdihar Omar ${ }^{a^{*}}$ and Nik Hasnaa Nik Mahmood ${ }^{a}$
}

${ }^{a}$ Razak Faculty of Technology and Informatics, Universiti Teknologi Malaysia, UTM Kuala Lumpur, 54100, Malaysia

\section{H R O N I C L E}

\section{Article history:}

Received: June 26, 2020

Received in revised format:

June 302020

Accepted: July 26, 2020

Available online:

July 26, 2020

Keywords:

Training and Development

Organizational Culture

Organizational Performance

\section{A B S T R A C T}

Training and development have been applied in many aspects for organization performance. The purpose of this study is to investigate the relationships between training and development and organizational performance. In addition, the study also analyzes the influence of organizational culture as a mediator in the relationship between training and development and organizational performance. The data are analyzed using descriptive and inferential statistics. IBM Statistical Package for the social sciences software (IBM-SPSS) version 23 and Smart Partial Least Square (SmartPLS) version 4.3 were used to evaluate the hypotheses of the study. The survey of the study involved 219 employees in courier service organizations in Malaysia. The finding of the study shows that there was a positive relationship between training and development and organizational performance. Furthermore, the finding also reveals that organization culture mediate the relationship between training and development and organization performance. Hence organizations should consistently train and develop their employees through formal and informal training programs as well as encourage employees to embrace organizational culture and values as well as cultivate the core values of organizational culture amongst employees to strengthen and improve organizational performance.

(C) 2020 by the authors; licensee Growing Science, Canada

\section{Introduction}

The challenges faced by the public and private sector call for a structural change and a paradigm shift for organizations to continue its existence and stay relevant. To achieve this goal, both public and private service workers' efficiency and performance must be at a certain level. There are various denotations and interpretations of organizational performance. According to Richard et al. (2009), organizational performance can be understood through many different meanings and interpretations which are diverse and encompasses three specific areas, namely; (a) financial performance (profit, assets, investment, etc.), (b) market product performance (sales, stock market, etc.); and (c) shareholders (number of shares, economic value added, etc.). Chen and Barnes (2006) points out that organizational performance is defined as the "input" to "output" transformation to achieve a specific outcome, which refers to the effective and minimal cost-effectiveness relationship with the effective costeffectiveness of 'output' or expected outcomes. According to Mamat (2001) training in organizations is a learning program designed to enhance employees' knowledge, skills, and performance. In addition, training is a process of changing the behavior of employees in the workplace through the application of the principles of learning. Kleiman (2004) defines training and development as a learning experience designed to teach employees how to effectively perform current and future tasks. Krempl and Pace (2001) state that training and development refers to knowledge management in developing organizational culture, to enhance individual performance and to strengthen organization's ability. Swanson et al. (2001) define training and development as a systematic process of knowledge-related work development and employees' skills development for performance improvement.

* Corresponding author.

E-mail address: md.izdihar@gmail.com (M. I. Omar) 
The role of organizational culture especially in terms of employee behavior as an intermediary variable in relation to training and development practices and organizational performance also needs to be taken into consideration as strong organizational culture can impact organizational performance (Cameroon \& Quinn 2006). Therefore, this study seeks to examine the role of training and development on improving organizational performance through organizational culture in the courier services sector.

\section{Literature Review}

\subsection{Training and Development and Organizational Performance}

Training and human resource development is one of the most important activities in an organization. They have been used in many aspects of organizational and individual development (Zenger et al., 2000). Therefore, both private and public organizations often allocate large funds for the planning and implementation of human resource training and development programs in their organizations. This shows that this development program can benefit the organization (Baharom 2009). Studies by Raza (2014) in several oil and gas companies in Pakistan indicated that training and development has a positive and significant relationship with organizational performance. The objective of the study was to examine the relationship between training and development and its impact on organizational performance. To measure this relationship, primary data were collected, and regression analysis was performed in oil and gas sector workers in Pakistan. The results of the training and development study in Pakistan showed that most of the workers had been satisfied with the training and development of the organization. These findings helped management focus on training and development to enhance the skills needed by employees to improve organizational performance. Muhibat and Tiamiyu (2016) carried out a study based on the effect of training and staff development on the organizational performance of Islamic financial institutions in Nigeria. It was also proven that training improves employees' performance on one hand and has a positive effect on the financial and non-financial performance of organizations on the other hand. Nda and Fard (2013) in their study found that training and development ultimately upgrade not only the productivity of employees but also of the organization. Falola et al. (2014) conducted a study in the Nigerian banking industry. The results of the study indicated that training and development affects employees' performance and organizational effectiveness. Consequently, efforts must be made to ensure that employees ${ }^{e e}$ skills and knowledge are fully utilized through adequate and timely training design and implementation. A study conducted by Ndibe and Campus (2014) in the Nigerian Bottling Company and 7UP Bottling Company showed that training and development has a direct impact on organizational performance. The study indicated that when employees are sent to the right training program through systematic and strategic training procedures, it contributes to the improvement of organizational performance and indirectly contributes to organizational performance. Thus, we hypothesize as follows:

$\mathbf{H}_{1}$ : There is a relationship between training and development and organizational performance.

\subsection{Training and Development, and Organizational Culture}

Every organization has its own beliefs, values, and cultural norms. Every organizational culture varies from business to business depending on the organization's policies. Organizational culture is defined as the system of expectations, ethics, attitudes, and principles that govern the work of employee within the organization. Training is a short-term process in which human resources gain knowledge, skills, and abilities through practical activities to improve their performance. The purpose of this training is to convey skills to perform a task. It improves organizational productivity and flexibility. Training helps employees do their work effectively and efficiently (Kissack \& Callahan 2010). This study also claimed that training and development programs influence organizational culture. Khan et al. (2017) focused on organizational culture that helps employees improve their skills, knowledge, skills, and experience in the organization. The sample size was 20 employees, from whom the results were obtained, in a survey on the influence of organizational culture on training effectiveness. In this study, it is found that most workers were influenced by their organizational culture during training. In addition, new skills, knowledge, attitudes, and capabilities were enhanced with training as well as improving employee organizational culture. Organizational culture plays an important role in every organization and some organizations had a strong culture whilst some do not. Thus, we hypothesize as follows:

H2: There is a relationship between training and development and organizational culture.

\subsection{Organizational culture with organizational performance}

Rashid et al. (2003) conducted a study on the influence of corporate culture and organizational commitment on the financial performance of Malaysian companies. The findings of the study have shown that there was a significant and positive relationship between corporate culture and organizational commitment and financial performance. The results of this study have important implications for human resource development and motivating workers. This study also demonstrates that corporate culture and organizational commitment had an impact and influence the company's financial performance. This means that the type of corporate culture and organizational commitment can be an important factor in determining a company's outstanding performance or success. Kandula (2006) said, the key to be a good performance is a strong culture. Positive and strong 
cultures can make an average individual perform and achieve excellence, while a negative and weak culture may fluctuate in the workforce to perform and end with no success. According to Magee (2003) contends that without considering the impact of organizational culture, organizational practices such as performance management could be counterproductive due to the two are interdependent and change in one will impact the other. According to Sørensen (2002), stronger culture could lead to high organizational performance. Furthermore, organizational level, culture, values, and work force diversity are major features which affect the relationships between training and development and organizational performance. (Youndt et al. 1996; Ferris et al. 1999). Thus, we hypothesize as follows:

$\mathbf{H}_{3}$ : There is a relationship between organizational culture and organizational performance.

There have been several studies that examined the role of organizational culture as mediator in the relationship between strategic human resource management and organizational performance. Mei et al. (2012) conducted a study to examine the mediating effect of organizational culture on the relationship between human resource management (HRM) and organizational performance through structural equation modelling. The study is based on survey design and cross-sectional nature. A total of 137 questionnaires were distributed and recovered and were used in statistical analysis. The HRM practices they have studied include hiring, performance evaluation, training and development, performance-based rewards, career management, information sharing, and job security. Nearly 57 percent of the variance in organizational culture constructs can be explained by HRM constructs. While both HRM constructs and organizational culture account for about 68 percent of the variance in organizational performance constructs. Structural equation models show that organizational culture plays a role in mediating the relationship between HRM and organizational performance

H4: Organizational culture acts as a mediator between training and development and organizational performance.

\subsection{Related Theory}

This study uses the Resource Based View (RBV) theory as the underlying theory of the study (Barney et al. 2001). According to RBV theory, one of the most important sources of organization is the human resource. If an organization adopts the RBV theory indirectly, it will impact the effectiveness of the competitive advantage. The theory also states that organizational culture also influences organizational performance and competitiveness.

From the discussion of the literature review and related theory above, the research framework of the impact of training and development on organizational performance through organizational culture is developed as shown in Fig. 1. Based on previous studies on the relationship between training and development with organizational performance and RBV theory, this study predicts there is relationship between training and development and organizational performance as well as there is mediating effect of organizational culture on relationship between training and development and organizational performance. This led to the formation of the first hypothesis to the fourth hypothesis of this study as shown in Fig. 1 below.

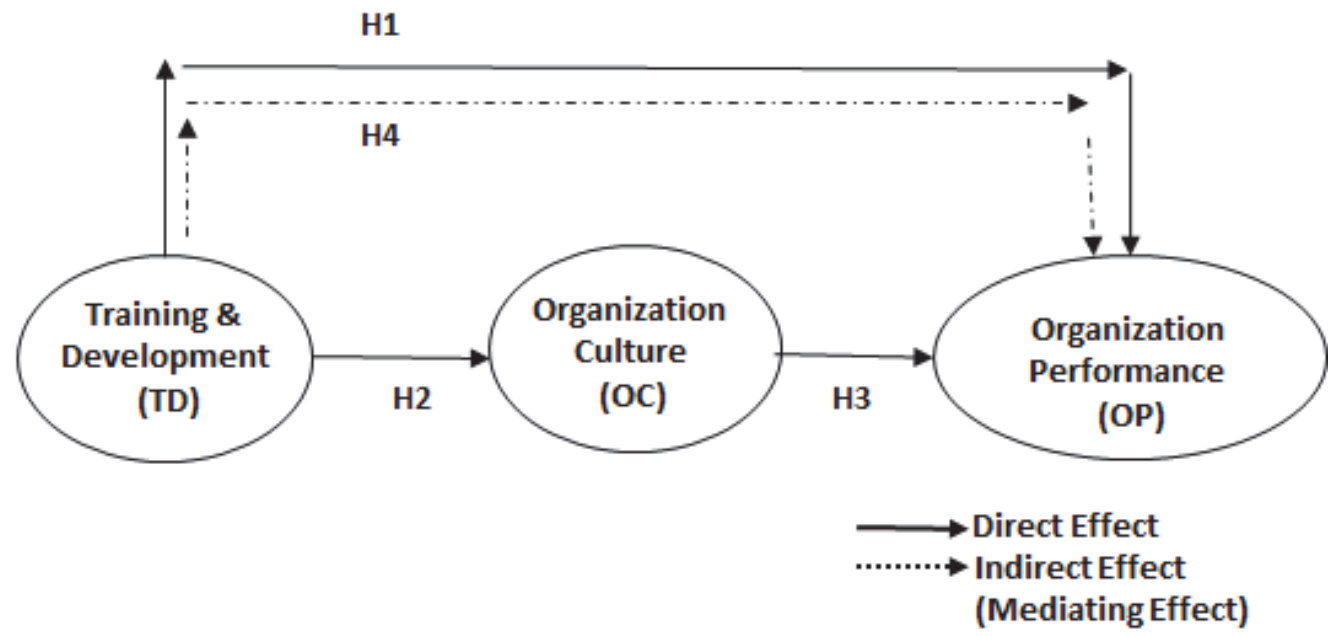

Fig. 1. Research framework

\section{Research methodology}

This study aims to examine the relationship between training and development and organizational performance as well as the impact of training and development on organizational performance. The research design selected for this study is quantitative 
method through survey. According to Sincero (2012) surveys can be administered to the participants through a variety of ways. The questionnaires can simply be sent via e-mail or fax or can be administered through the Internet. Nowadays, the online survey method has been the most popular way of gathering data from target participants. Aside from the convenience of data gathering, researchers can collect data from people around the globe. Because of the high representativeness brought about by the survey method, it is often easier to find statistically significant results than other data gathering methods. Multiple variables can also be effectively analyzed using surveys. Based on the objective of this study, the survey is the best method to be used. Data was collected through surveys using questionnaire because questionnaire is the most common technique used in research survey. This would ensure the data matrix inclusivity. The researchers developed research instrument to collect quantitative data and the research instruments were adapted from Cassell et al. (2002) in measuring training and development, Denison and Mishra (1995) in measuring organizational culture and Haldma et al. (2012), Athanassopoulos et al. (2001), Caruana (2002), Spangenberg and Theron (2004) in measuring organizational performance. Prior to the distribution of the questionnaire, expert validation to validate the instrument for every construct was conducted. After consulting for validation with expertise and making some amendment, questionnaire was distributed among the employees in courier service organizations in Malaysia. Respondents were given of three weeks to complete and return to the researcher. Out of a total of 300 sets of questionnaires, researchers managed to find 219 questionnaires that could be used. IBM Statistical Package for the social sciences software (IBM-SPSS) version 23 and Smart Partial Least Square (SmartPLS) version 4.3 were used to evaluate the hypothesis of the study. Finally, the measured indicators for every construct were based on five-point Likert scale.

\subsection{Analysis of data and the result}

\section{Respondent profile}

Fig. 2 shows the summary of the respondents' profile among employees in selected departments in courier service organizations in Malaysia. The results show that 62.0 percent of the respondents were male. Majority of the respondents' age ranges between 31 to 40 years old at 41.0 percent. Overall, the respondents were predominantly Malay and most of the respondents had served between two to four years at 97.0 percent. On qualifications, 54.0 percent of the respondents possessed other type of education certificate and $102(46 \%)$ respondents are supervisors.

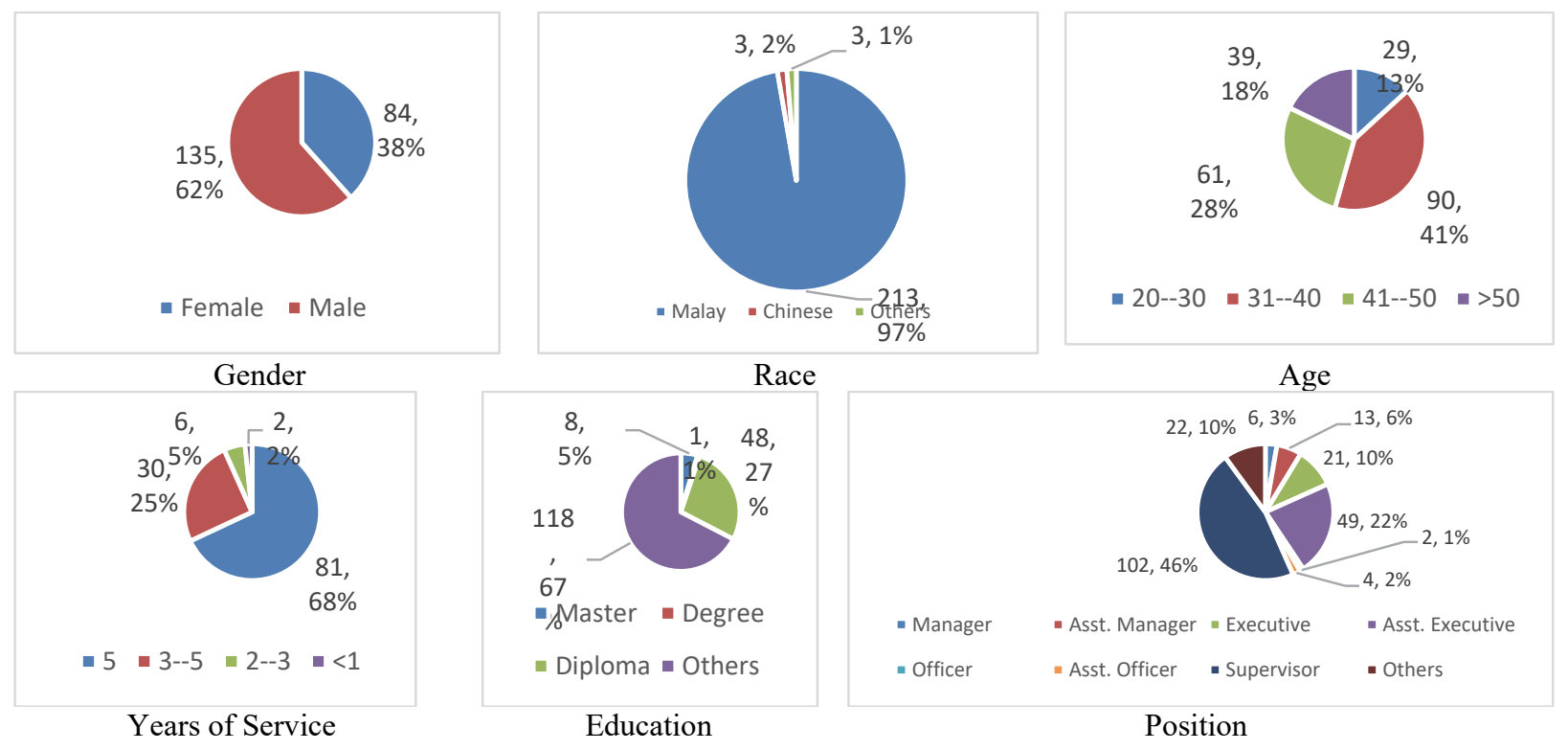

Fig. 2. Demographic data of the respondents.

\section{Measurement Model}

\subsection{Internal Consistency $(\alpha, \rho c)$}

The reflective measurement model analysis includes three types or assessments which are internal consistency, convergent validity and discriminant validity. The measurement model in convergent validity assessment had concluded that the result for this study lies in the threshold range (Hair et al., 2017; Fornell \& Larcker, 1981). Internal consistency for this research instruments was assessed by computing the value of Cronbach's alpha and composite reliability. Table 1 shows the value for each construct. Training and development $(\alpha=0.891, \rho c=0.910)$, Organizational Culture $(\alpha=0.906, \rho c=0.921)$ and Organizational Performance $(\alpha=0.943, \rho c=0.949)$. According to Hair et al. (2010), all values resulted 0.70 is highly suggested as the level of acceptance. For Average Variance Extracted, every latent construct has exceeded the minimum threshold proposed value which is 0.50 (Hair et al., 2017). Therefore, from the result attained, the indicator for each latent construct are well 
explained and correlate with each other. The indicators assigned at each latent can be said reflect well as the observed variables. Table 1 shows the value of AVE for each construct where training and development (AVE =0.505), Organizational Culture $(\mathrm{AVE}=0.516$, and Organizational Performance $(\mathrm{AVE}=0.557)$.

Table 1

Cronbach alpha and composite reliability

\begin{tabular}{lccc} 
& Cronbach's Alpha & Composite Reliability & AVE \\
\hline Training and Development & 0.891 & 0.910 & 0.505 \\
Organization Culture & 0.906 & 0.921 & 0.516 \\
Organization Performance & 0.948 & 0.949 & 0.557 \\
\hline
\end{tabular}

The researcher proceeds with the assessment which is discriminant validity. According to Ramayah et al. (2018), the discriminant validity refers to the degree of which indicators differentiate across constructs. This is to avoid any overlapping happen between each correlation. In this research, the measurement of discriminant validity is carried out through Fornell \& Larcker, cross loading criterion and Heterotrait-Monotrait ratio of correlation (HTMT). Fornel \& Larcker criterion needs for comparing the diagonal section should be larger than the off-diagonal correlation. HTMT criterion has been analysed according to inference HTMT by (Henseler, Ringle, and Sarstedt, 2014). In this HTMT inference, the value of confidence interval should be less than 1.0 by using the bootstrapping technique, (Henseler et al., 2015). therefore, the following tables are generated based on the result attained for discriminant validity assessment. Table 2, and Table 3 show the summary of results for discriminant validity on Fornell and Larcker criterion, HTMT criterion and cross loading criterion.

Table 2

Fornell-Larcker Criterion

\begin{tabular}{lccc} 
& Organization Culture & Training and Development & Organization Performance \\
\hline Organization Culture & 0.718 & & \\
Training and Development & 0.536 & 0.711 & 0.308 \\
Organization Performance & 0.708 & 0.746 \\
\hline
\end{tabular}

Table 3

Heterotrait-Monotrait Ratio (HTMT)

\begin{tabular}{lccc}
\hline & Organization Culture & Training and Development & Organization Performance \\
\hline Organization Culture & & & \\
Training and Development & 0.587 & 0.322 \\
Organization Performance & 0.756 & \\
\hline
\end{tabular}

\subsection{Assessment of Collinearity Issue}

According to Kock (2015), collinearity helps in measuring similarity of two or more indicators that are in the same domain. In this step of assessment, the rule of thumb is less than 5.0 as suggested by Hair et al. (2016). The values of variance inflation factor (VIF) were less than 5.0. Table 4 presents the summary for the outer VIF value across constructs. There are three main constructs and each construct exceeds the rule of thumb as suggested by Hair et al. (2016). The construct for training and development indicates the value of outer VIF by $1.612,1.753$ and organization culture at 1.948 . Hence the assessment for VIF has been fulfilled.

Table 4

Summary of outer VIF across construct

\begin{tabular}{|c|c|c|c|}
\hline Latent Construct & Training and Development & Organization Culture & Organization Performance \\
\hline Training and Development & & 1.612 & 1.753 \\
\hline Organization Culture & & & 1.948 \\
\hline Organization Performance & & & \\
\hline
\end{tabular}

\subsection{Structural Model Assessment}

\section{Assessment of the significance and relevance of relationship}

In this study, the procedure of the bootstrapping technique was used with 3000 subsamples. The large sample is needed for identifying and detecting any bootstrapping standard error. According to Ramayah et al. (2018), researchers should observe the path coefficients that are significant to the tested hypotheses between constructs. After conducting a bootstrapping procedure, the following results are found and can be seen in Table 5. Based on $\mathrm{t}$ statistics for the three direct relationship between exogenous and endogenous, the first, second and third hypothesis are accepted. 
The assessment level for a coefficient of determination measuring model's accuracy was based on both exogenous and endogenous constructs. Statistically, this assessment range was between 0 to 1 in explaining the level of accuracy and the association of exogenous and endogenous constructs (Ramayah et al., 2018). Table 5 shows the summary coefficient of the determination result for this study. The result of the exogenous constructs (training and development) explains the endogenous variables at (Organization Culture $=0.487$ ) and (Organization Performance $=0.571)$. According to Hair et al. $(2016)$ the level of coefficient of determination that range on 0.25 are considered weak, 0.50 moderate and 0.75 is substantial. Therefore, based on the results attained, this assessment for coefficient determination falls between weak and moderate according to the acceptance rule of thumb.

\section{Assessment Level of $f^{2}$, (Effect Size)}

The research proceeds with the next step which is an assessment on the level of effect size $\left(\mathrm{f}^{2}\right)$. The evaluation size of the construct predictor is using Cohen's $\mathrm{f}^{2}$ (Cohen, 1988). The rule of thumb also has been set accordingly. Specifically, the effect size of 0.02 is considered a small effect size, the value or 0.15 has a medium effect size and lastly, the value of 0.35 has a substantial effect size. Table 5 is tabulated the summary result of effect size. Based on the result Table 5 show that training and development has small effect size on organizational performance (0.039) and organizational culture (0.087). In contrast, organizational culture has substantial effect size on organizational performance (0.397). Therefore, this study concluded that the effect size of $\mathrm{f}$ squared are lies from small to substantial effect size based on the suggestion by (Cohen, 1988).

\section{Assessment Level of $Q^{2}$, (Predictive Relevance)}

Another step of structural model is the assessment of predictive relevance with the value of Q squared. This assessment is used to evaluate the predictive accuracy of the path model (Ramayah et al., 2018). This predictive relevance value can be statistically obtained from the blindfolding technique procedure. A structural model that achieve more than the acceptance level considered having a higher predictive relevance of path model. Table 5 presents the summary of the predictive relevance that gives the value of Q squared. The predictive relevance value Q squared of training and development obtained the value of 0.245 and organizational culture has a value of 0.240 . The level of acceptance in interpreting the Stone and Geisser Q2 predictive relevance value should be larger than the value of 0, (Hair et al., 2017; Stone, 1974; Geisser, 1975). Based on the result obtained, the value indicated larger than 0 , thus the model has sufficient predictive relevance.

Table 5

Summary of significance and relevance relationship

\begin{tabular}{|c|c|c|c|c|c|c|c|c|c|c|}
\hline Hypothesis & Relationship & $\begin{array}{c}\text { Std } \\
\text { Beta }\end{array}$ & $\begin{array}{c}\text { Std } \\
\text { Error }\end{array}$ & t-value & $\mathrm{p}$-value & Decision & $\mathrm{R}^{2}$ & $f^{2}$ & $\mathrm{Q}^{2}$ & VIF \\
\hline $\mathrm{H} 1$ & Significant & 0.170 & 0.082 & 2.065 & 0.039 & Supported & 0.287 & 0.039 & 0.245 & 1.753 \\
\hline $\mathrm{H} 2$ & Significant & 2.69 & 0.074 & 3.629 & 0.000 & Supported & 0.487 & 0.087 & 0.240 & 1.612 \\
\hline H3 & Significant & 0.576 & 0.082 & 7.065 & 0.000 & Supported & 0.571 & 0.397 & & 1.948 \\
\hline
\end{tabular}

Notes: $\mathrm{t}$ values $>1.65 *(\mathrm{p}<0.10)$; $\mathrm{t}$ values $>1.96 * *(\mathrm{p}<0.05) ; \mathrm{t}$ values $>2.58 * * *(\mathrm{p}<0.001)$

\section{Mediation Analysis}

According to Hair et al. (2016), mediation also known as indirect effect and the mediation can be beneficial in determining the association between independent and dependent constructs. In this study, a further test on mediation analysis is applied to organization culture as a mediator to investigate the role in mediating between training and development and organization performance. According to Preacher and Hayes (2008), the mediation analysis requires the bootstrapping procedure for assessing the mediator constructs. Table 6 shows the hypothesis on the mediation report analysis. As shown in Table 6 , organization culture mediates significantly between training and development and organization performance. Therefore, H4 is accepted.

Table 6

Hypothesis on mediation report analysis result

\begin{tabular}{|c|c|c|c|c|c|c|c|}
\hline \multirow[t]{2}{*}{ Hypothesis } & \multirow[t]{2}{*}{$\begin{array}{c}\text { Beta } \\
\text { Value }\end{array}$} & \multirow[t]{2}{*}{$\begin{array}{l}\text { Standard Devi- } \\
\text { ation (STDEV) }\end{array}$} & \multirow[t]{2}{*}{$\begin{array}{c}\text { T Statistics } \\
(|\mathrm{O} / \mathrm{STDEV}|)\end{array}$} & \multirow[t]{2}{*}{$\begin{array}{c}\mathrm{P} \\
\text { (Value) }\end{array}$} & \multicolumn{2}{|c|}{$\begin{array}{c}\text { Confidence Interval } \\
\text { (BC) }\end{array}$} & \multirow[t]{2}{*}{ Decision } \\
\hline & & & & & LL & UL & \\
\hline $\begin{array}{l}\text { Training and development } \rightarrow \text { Organiza- } \\
\text { tion culture } \rightarrow \text { Organization performance }\end{array}$ & 0.155 & 0.047 & 3.279 & 0.001 & 0.075 & 0.261 & Supported \\
\hline
\end{tabular}

\section{Summary and conclusion}

This study intended to present empirical evidence of the relationship between training and development and organizational performance among employees in selected department in courier service organizations. This study also examined whether organizational culture was able to play the mediating role in linking between training and development and organizational performance among employees. The indicator of training and development shows t-value at $2.065(\beta=0.170, \mathrm{p}<0.039)$ and 
is positively correlated with organizational performance. The indicator of training and development shows t-value at $3.629(\beta$ $=0.269, \mathrm{p}<0.01)$ and is positively related to organizational culture. Organizational culture shows t-value at $7.065(\beta=0.576$, $\mathrm{p}<0.01$ ) is also positively related to organizational performance. Furthermore, the fourth hypothesis is assessing the mediation role of organizational culture practices in linking between training and development and organizational performance shows the $\mathrm{t}$-value at $3.279(\beta=0.155, \mathrm{p}<0.01)$ which supported the hypothesis generated.

Based on the findings and previous studies, investment in training and development will result in increasing organizational performance. The finding of this study for hypothesis H1 is consistent with the studies conducted by Niazi (2011) at FMCG and a study by Raza (2014) on several oil and gas companies in Pakistan which showed a strong relationship between training and development and organizational performance. Therefore, the organization should leverage on training and development to optimize employee effectiveness and retain their best key person in the pursuit to become one of the main key players in this sector (Zenger et al. 2000; Baharom 2009). The research finding for hypothesis $\mathrm{H}_{2}$ shows a significance influence of training and development on organizational culture. This finding is aligned with studies conducted by Kissack and Callahan 2010 and Khan et al. (2017). Both studies found that training and development support internalization of organizational culture. Tying employee learning, training and development to a positive workplace culture shows people what's in it for them. (Chris, 2019). The third research hypothesis $\mathrm{H}_{3}$ also revealed a significant effect of organizational culture towards organizational performance. This finding supports the past studies by Kandula (2006), Magee (2003) and Sorensen (2002). Their studies proved that positive and strong culture lead to high organizational performance. All training and development investments (and other important decisions) should be made with these organizational cultural objectives in mind. In addition, the finding of the hypothesis $\mathrm{H}_{4}$ reveals that organization culture also plays a mediating role between training and development and organizational performance. This finding is consistent with studies conducted by Mei et al. (2012) which found the mediating effect of organizational culture in the relationship between strategic human resources management and organizational performance whereby one of the strategic human resources management elements measured is training and development. Hence, progressive intervention of organizational culture practices is needed in managing employees and helps the organization maximize its productivity. The public servicing sector such as courier services remains as one of the fastest evolving sectors due to globalization and the changing of technology should leverage on both training and development and organizational culture in enhancing organizational performance.

In the light of this research, future scholars may replicate with a different context of respondents, sectors or other talent challenges constructs. Researchers should explore carrying out studies involving respondents from other sectors such as manufacturing and petroleum. Future researchers are also recommended to study the role of organizational culture in improving human resource development and organizational performance through in-depth interviews and observations with the organization members.

In conclusion, the organization should consistently train and develop their employees through formal and informal training program as well as encouraging employees to embrace organizational culture and values to help improve organizational performance.

\section{References}

Athanassopoulos, A., Gounaris, S., \& Stathakopoulos, V. (2001). Behavioural responses to customer satisfaction: an empirical study. European Journal of Marketing, 35(5/6), 687-707.

Baharom, A. (2009). Implementation of human resource training policy in Malaysian public universities, Universiti Malaya.

Barney, J., Wright, M., \& Ketchen Jr, D. J. (2001). The resource-based view of the firm: Ten years after 1991. Journal of management, 27(6), 625-641.

Cameroon, K. S., \& Quinn, R. E. (2006). Diagnosing and Changing Organizational Culture-Based on the Competing Values Framework. Revised ed, USA: John Wiley \& Sons.

Caruana, A. (2002), Service loyalty: The effects of service quality and the mediating role of customer satisfaction. European Journal of Marketing, 36(7/8), 811-828.

Cassell, C., Nadin, S., Gray, M., \& Clegg, C. (2002). Exploring human resource management practices in small and medium sized enterprises. Personnel Review, 31(6), 671-692.

Chen, L. Y., \& Barnes, F. B. (2006). Leadership behaviors and knowledge sharing in professional service firms engaged in strategic alliances. Journal of Applied Management and Entrepreneurship, 11(2), 51.

Denison, D. R., \& Mishra, A. K. (1995). Toward a theory of organizational culture and effectiveness. Organization science, $6(2), 204-223$

Falola, H. O., Osibanjo, A. O., \& Ojo, I. S. (2014). Effectiveness of training and development on employees' performance and organisation competitiveness in the nigerian banking industry. Bulletin of the Transilvania University of braşov, 7(1), 161.

Ferris, G. R., Hochwarter, W. A., Buckley, M. R., Harrell-Cook, G., \& Frink, D. D. (1999). Human resources management: Some new directions. Journal of Management, 25(3), 385-415..

Hair Jr, J. F., Sarstedt, M., Matthews, L. M., \& Ringle, C. M. (2016). Identifying and treating unobserved heterogeneity with FIMIX-PLS: part I-method. European Business Review, 28(1), 63-76. 
Haldma, T., Näsi, S., Grossi, G., Hernaus, T., Bach, M. P., \& Vukšić, V. B. (2012). Influence of strategic approach to BPM on financial and non-financial performance. Baltic Journal of Management, 7(4), 376-396.

Kandula, S. R. (2006). Performance management: Strategies, interventions, drivers. PHI Learning Pvt. Ltd.

Khan, U.R., Kanwal, K., \& Arshad, U. (2017). Influence of organizational culture on training effectiveness. International Journal of Multidisciplinary and Current Research, 5(April), 382-386.

Kissack, H. C., \& Callahan, J. L. (2010). The reciprocal influence of organizational culture and training and development programs. Journal of European Industrial Training, 34, 365-380.

Kleiman, L. S. (2004). Human resource management: A managerial tool for competitive advantage. Atomic Dog Publishing. ISBN-10: 1592602673. ISBN-13: 978-1592602674

Kock, N. (2015). Common method bias in PLS-SEM: A full collinearity assessment approach. International Journal of eCollaboration (ijec), 11(4), 1-10.

Krempl, S., \& R. W. Pace (2001). Training across multiple locations: Developing a system that works. Berrett-Koehler Publishers. Publisher: Berrett-Koehler Publishers; First Edition edition (May 14, 2001). ISBN-10: 1576751570. ISBN13: $978-1576751572$

Magee, K. C. (2002). The impact of organizational culture on the implementation of performance management (Doctoral dissertation). Available from Dissertations and Theses database (UMI No. 3047909)

Mamat, I. (2001). Reka bentuk dan pengurusan latihan: Konsep dan amalan. Dewan Bahasa dan Pustaka.

Mei, T. S., Yahya, K. K., \& Teong, L. K. (2015). Hubungan Antara Pengurusan Sumber Manusia, Budaya Organisasi dan Prestasi Organisasi: Pemodelan Persamaan Struktur. International Journal of Management Studies, 22(1), 97-112.

Muhibat, A., \& Tiamiyu, L. (2016). Empirical evaluation of effect of training \& staff development on organization performance of Islamic financial institutions in Nigeria. Business and Management Research Journal, 6(10), $109-117$.

Nda, M. M., \& Fard, R. Y. (2013). The impact of eployee training and development on employee productivity. Global journal of commerce and management perspective, 2(6), 91-93.

Ndibe, B. C, \& Campus, E. (2014). Effect of employees training on organizational performance in soft drinks bottling cmpanies in Enugu State, Nigeria. Faculty of Business Administration, University of Nigeria Enugu Campus.

Niazi, A. S. (2011). Training and development strategy and its role in organizational performance. Journal of public Administration and Governance, 1(2).

Hayes, A. F., Slater, M. D., \& Snyder, L. B. (Eds.). (2008). The Sage sourcebook of advanced data analysis methods for communication research. Sage.

Ramayah, T., Cheah, J., Chuah, F., Ting, H., \& Memon, M. A. (2018). Partial least squares structural equation modeling (PLS-SEM) using smartPLS 3.0. In An Updated Guide and Practical Guide to Statistical Analysis. Pearson.

Rashid, Z. A., Sambasivan, M., \& Johari, J. (2003). The influence of corporate culture and organisational commitment on performance. Journal of management development, 22(8), 708-728.

Raza, H. (2014). Training and development impact on organizational performance: Empirical evidence from oil and gas sector of Pakistan. IOSR Journal of Business and Management (IOSR-JBM), 16(1), 67-72.

Richard, P. J., Devinney, T. M., Yip, G. S., \& Johnson, G. (2009). Measuring organizational performance: Towards methodological best practice. Journal of management, 35(3), 718-804.

Sincero, S. M. (2012). Advantages and Disadvantages of Surveys.

Sørensen, J. B. (2002). The strength of corporate culture and the reliability of firm performance. Administrative Science Quarterly, 47(1), 70-91.

Spangenberg, H., \& Theron, C. (2004). Development of a questionnaire for assessing work unit performance. SA Journal of Industrial Psychology, 30(1), 19-28.

Swanson, R. A., Holton, E., \& Holton, E. F. (2001). Foundations of human resource development. Berrett-Koehler Publishers.

www.thehrdirector.com/features/learning-development/training-development-programmes-affect-company-culture224/How training and development programmes affect company culture

Youndt, M. A., Snell, S. A., Dean Jr, J. W., \& Lepak, D. P. (1996). Human resource management, manufacturing strategy, and firm performance. Academy of Management Journal, 39(4), 836-866.

Zenger, J., Ulrich, D., \& Smallwood, N. (2000). The new leadership development. Training \& Development, 54(3), $22-22$.

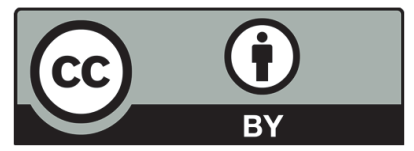

(C) 2020 by the authors; licensee Growing Science, Canada. This is an open access article distributed under the terms and conditions of the Creative Commons Attribution (CC-BY) license (http://creativecommons.org/licenses/by/4.0/). 